\title{
Clonality of CD3 negative large granular lymphocyte proliferations determined by PCR based $\mathrm{X}$-inactivation studies
}

\author{
A Kelly, S J Richards, M Sivakumaran, C Shiach, A D Stewart, B E Roberts, C S Scott
}

Molecular Pathology and Haematological Malignancy Diagnostic Service, Algernon Firth Building, University of Leeds, Leeds LS2 9JT

A Kelly

S J Richards

M Sivakumaran

C Shiach

B E Roberts

C S Scott

Department of

Genetics, University

of Leeds, Leeds LS2

9JT

A D Stewart

Correspondence to:

Angela Kelly

Accepted for publication

3 November 1993

\begin{abstract}
Aims-To examine persistent CD3- large granular lymphocytosis (LGL) cases for clonality, both by lineage specific ( $T$ cell receptor) and lineage independent (X-inactivation) molecular methods; and to find out whether $\mathrm{X}$-inactivation studies are more appropriate than gene rearrangement studies for this subset of LGL disorders.

Methods-Patients were selected who had LGL of more than six months' duration and identified as CD3 - by immunophenotyping. $T$ cell receptor studies and, where possible, $\mathrm{X}$-inactivation studies of the phosphoglycerate kinase (PGK) gene were carried out. Analysis of subpopulations was carried out on cases heterozygous for PGK by the use of a polymerase chain reaction (PCR) method for $X$ inactivation.
\end{abstract}

Results-Of 17 CD3- LGL cases studied, all were found to be germline for $\beta, \gamma$, and $\delta \mathbf{T}$ cell receptor studies, and immunoglobulin heavy chain genes. However, six of these were analysed by $\mathrm{X}$-inactivation of the PGK gene and two cases gave clonal band patterns but only within the CD3-subpopulation.

Conclusions-Clonal analysis by the lineage independent method of $X$ inactivation allows clonal expansion undetected by $T$ and $B$ cell specific markers to be identified. It is therefore a more appropriate method for the analysis of CD3- LGL. This has implications for diagnosis in CD3- LGL disorders.

(F Clin Pathol 1994;47:399-404)

However, a recent survey by the Yorkshire Leukaemia Group (YLG) indicates that about $25 \%$ of persistent LGL expansions are in fact of CD3 - type, and a proportion of these are also thought to be clonal in nature. ${ }^{56}$

Monoclonality is a fundamental characteristic of haemopoietic malignancies, and investigations to establish the clonal nature of abnormal proliferations are therefore important in differentiating reactive from malignant states. The most widely used method for assessing clonality of lymphoid disorders involves molecular analysis of immunoglobulin and $T$ cell receptor (TCR) gene rearrangements. ${ }^{27}$ TCR studies are informative for most cases of CD3 + malignancy, ${ }^{8}$ but TCR studies of $\mathrm{CD} 3$ - proliferations have been of little value. ${ }^{39}$

An alternative method of clonal analysis is provided by the study of differential methylation in certain $\mathrm{X}$ chromosome genes in females. ${ }^{10}$ The inactivation of one $X$ chromosome with concomitant methylation of the $5^{\prime}$ end of genes, such as PGK and hypoxanthine phosphoribosyl transferase (HPRT) during early embryogenesis, provides a stably inherited genetic marker. A normal population of cells in an adult woman will comprise a random mixture of paternally and maternally derived $\mathrm{X}$-inactivated cells. A clonal population of cells, having originated from a single cell, will feature inactivation of the same $X$ chromosome in each cell. The PGK gene can be used for clonal analysis by a polymerase chain reaction (PCR) method where amplification of DNA around the BstXI polymorphic restriction site and a methylation site permits analysis of heterozygous females. ${ }^{11}$ The $B s t \mathrm{XI}$ site is polymorphic in about $33 \%$ of females. ${ }^{10}$

To examine the nature of persistent increases in CD3 - LGL/natural killer cells, we analysed $\mathrm{X}$-inactivation at the PGK locus in six informative women from 17 female CD3 - cases identified in the YLG survey. ${ }^{5}$ large granular lymphocytes (LGL) are assoc ated with a diverse range of disorders, including both reactive and malignant conditions. ${ }^{1}$ Transient (acute reactive) LGL expansions occur primarily in response to viral infections and are often characterised by increases in both CD3 + T cell and CD3 - natural killer cell LGL. ${ }^{2}$ In contrast, persistent lymphocytoses with granular morphology are generally due to an abnormal expansion of one LGL type. ${ }^{3}$ Many persistent LGL expansions with clinical and haematological features of "leukaemia" have been reported, and most cases designated as such by the MorphologyImmunology-Chromosome (MIC) Cooperative Study Group are of the CD3 + subtype. ${ }^{4}$

\section{Methods}

To date the YLG survey has identified 97 people with persistently increased LGL and/or lymphocytes expressing natural killer cell associated membrane determinants (defined as lasting more than six months). ${ }^{5}$ Of these, 23 were found with a primary increase in CD3 - natural killer cell associated + cells. Seventeen were women and were screened for heterozygosity at the polymorphic BstXI site in the PGK gene (fig 1). LGL lymphocytes were identified by conventional morphologi- 
Figure 1 Diagram of the exon 1 region of the $P G K$ gene showing positions of the HpaII and BstXI endonuclease sites and the primers used in the PCR method of $X$-inactivation analysis.

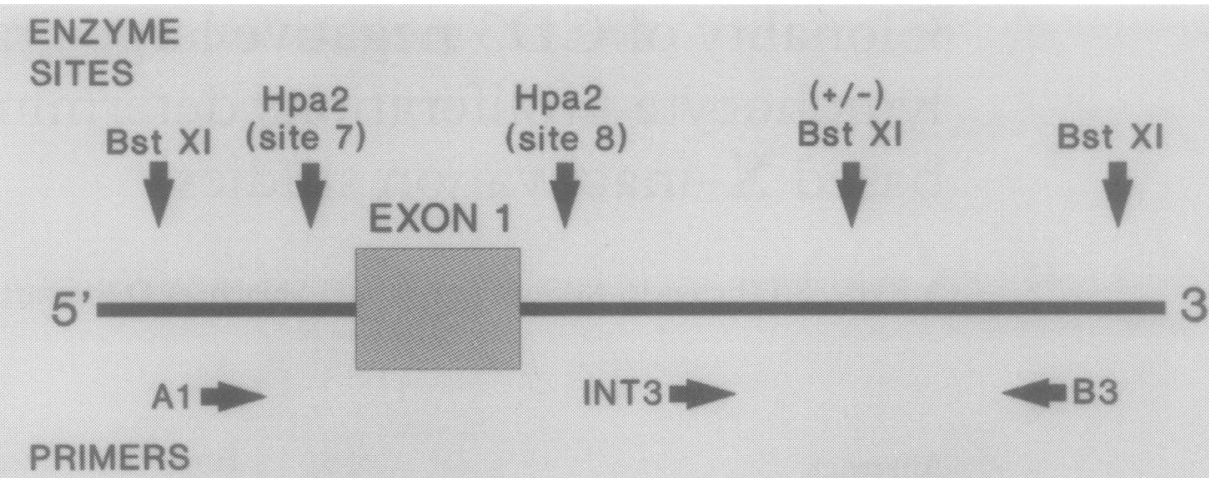

cal examination and benzylcarbonyl-L-lysine thiobenzyl (BLT) esterase cytochemistry. ${ }^{12}$ Lymphocyte counts and immunophenotypic data are shown in table 1. Age and clinical details of the six heterozygous cases identified by this screen are shown in table 2 .

\section{LYMPHOCYTE FRACTIONATION AND \\ IMMUNOMAGNETIC MODIFICATION \\ PROCEDURES}

Mononuclear cells were initially fractionated from $30 \mathrm{ml}$ of EDTA anticoagulated venous blood by density sedimentation with Lymphoprep (Nycomed, UK). Cells isolated from the interface were washed twice in phosphate buffered saline and azide (0.01\%) before immunophenotyping and immunomagnetic depletion procedures.

Washed mononuclear cells were pelleted and mixed with the following combination of monoclonal antibodies at saturating concentrations: 63D3 (CD14); HD37 (CD19); and T3 (CD3). After a 30 minute incubation at $4^{\circ} \mathrm{C}$, with occasional mixing, the cells were washed free of excess monoclonal antibodies and resuspended in $0.5 \mathrm{ml}$ Hanks' balanced salt solution (HBSS), supplemented with $1 \%$ bovine serum albumin (BSA). Washed sheep anti-mouse immunoglobulin coated M450 magnetic particles (Dynabeads; Dynal, UK) were added $(50 \mu \mathrm{l})$. The leucocyte/Dynabead mixture was incubated for 30 minutes at room temperature with gentle agitation, then resuspended to $1 \mathrm{ml}$ in $1 \% \mathrm{BSA} / \mathrm{HBSS}$ and placed on a magnetic separator. The unbound cells were removed and tested for residual antibody coated cells by indirect immunorosetting. ${ }^{13}$ The depletion procedure was repeated with further $50 \mu \mathrm{l}$ aliquots of Dynabeads until the number of residual monoclonal antibody cells

Table 1 Summary of haematological and immunophenotypic features of six CD3- natural killer cell associated + persistent expansions examined in this study ${ }^{\star}$

\begin{tabular}{|c|c|c|c|c|c|}
\hline Case No & $\begin{array}{l}\text { Lymphocyte } \\
\text { count } \times 10^{9} / l\end{array}$ & $\begin{array}{l}\% L G L \\
\text { IBLT† }\end{array}$ & $\begin{array}{l}\text { Absolute } \\
C D 2+C D 3- \\
\times 10^{\circ} / l\end{array}$ & $\begin{array}{l}\text { Primary natural killer cell } \\
\text { associated abnormality } \neq\end{array}$ & Natural killer cell associated phenotype $e^{\star \star}$ \\
\hline $\begin{array}{l}\text { AB } \\
\text { ZB } \\
\text { WD } \\
\text { WF } \\
\text { LG } \\
\text { AW }\end{array}$ & $\begin{array}{l}1 \cdot 7 \\
6 \cdot 3 \\
4 \cdot 7 \\
4 \cdot 4 \\
5 \cdot 9 \\
6 \cdot 0\end{array}$ & $\begin{array}{l}32 / 61 \\
06 / 39 \\
20 / 52 \\
36 / 69 \\
30 / 75 \\
42 / \mathrm{nt}\end{array}$ & $\begin{array}{l}0.73 \\
0.95 \\
1.41 \\
0.97 \\
2.42 \\
1.56\end{array}$ & $\begin{array}{l}\mathrm{CD} 2+\mathrm{CD} 3-\mathrm{CD} 4-\mathrm{CD} 8- \\
\mathrm{CD} 2+\mathrm{CD} 3-\mathrm{CD} 4-\mathrm{CD} 8- \\
\mathrm{CD} 2+\mathrm{CD} 3-\mathrm{CD} 4-\mathrm{CD} 8^{\mathrm{dim}+} \\
\mathrm{CD} 2+\mathrm{CD} 3-\mathrm{CD} 4-\mathrm{CD} 8^{\mathrm{dim}+} \\
\mathrm{CD} 2+\mathrm{CD} 3-\mathrm{CD} 4-\mathrm{CD} 8- \\
\mathrm{CD} 2+\mathrm{CD} 3-\mathrm{CD} 4-\mathrm{CD} 8-\end{array}$ & $\begin{array}{l}C D 11 b+C D 16+C D 56+C D 57+ \\
C D 11 b+C D 16 v+C D 56 v \text { CD57v } \\
C D 11 b+C D 16+C D 56+C D 57 v \\
C D 11 b+C D 16 v+C D 56+C D 57 v \\
C D 11 b+C D 16+C D 56 v \text { CD57v } \\
C D 11 b+C D 16+C D 56+C D 57+\end{array}$ \\
\hline
\end{tabular}

*These cases represent the six (of 17 tested) women who were shown in preliminary studies to be heterozygous for the PGK gene. † Indicates the percentages of lymphocytes with LGL morphology (Romanowsky) and positive BLT esterase staining. ¥ Indicates the composite (CD2/CD3/CD4/CD8) phenotypes of the natural killer cell associated populations that were the primary abnormalities in these patients.

$\star \star$ Composite natural killer cell associated phenotypes of the abnormally increased CD2 + CD3 - fractions in these patients (+ $\mathrm{v}$ and - indicate $>60 \%, 30-60 \%$, and $<30 \%$ of the CD2 $+\mathrm{CD} 3-$ fraction expressing the designated natural killer cell associated determinant).

Table 2 Summary of clinical data and DNA analysis

\begin{tabular}{|c|c|c|c|c|c|}
\hline \multirow[b]{2}{*}{ Case $\mathrm{No}^{*}$} & \multirow{2}{*}{$\begin{array}{l}\text { Age } \\
(y)\end{array}$} & \multirow[b]{2}{*}{ Clinical features } & \multirow[b]{2}{*}{ TCR study } & \multicolumn{2}{|c|}{$X$-inactivation $\ddagger$} \\
\hline & & & & $C D 3+$ & $C D 3-$ \\
\hline $\begin{array}{l}\text { AB } \\
\mathbf{Z B} \\
W D\end{array}$ & $\begin{array}{l}72 \\
40 \\
70\end{array}$ & $\begin{array}{l}\text { No important medical history } \\
\text { No important medical history } \\
\text { Polymyalgia rheumatica, gall stones, diverticulitis, }\end{array}$ & $\begin{array}{l}\text { Germline } \\
\text { Germline }\end{array}$ & $\begin{array}{l}\text { Poly } \\
\text { Poly }\end{array}$ & $\begin{array}{l}\text { Poly } \\
\text { Poly }\end{array}$ \\
\hline WF & 55 & $\begin{array}{l}\text { Hypothyroidism, maturity onset diabetes mellitus, } \\
\text { iron deficiency, menorrhagia, hysterectomy }\end{array}$ & Germline & Poly & Mono \\
\hline LG & 72 & $\begin{array}{l}\text { Transient headaches-resolved without treatment, } \\
\text { diverticulitis }\end{array}$ & Germline & Poly & Mono \\
\hline AW & 28 & $\begin{array}{l}\text { Clinically documented viral infection-monospot } \\
\text { negative. Now well }\end{array}$ & Germline & Poly & Poly \\
\hline
\end{tabular}

* These cases (six of 17 tested) are heterozygous for the BstXI polymorphism in the PGK gene. + Germline configuration of TCR genes was also found in 11 of $17 \mathrm{CD} 3-\mathrm{NKa}+$ cases tested, which were not polymorphic for PGK.

$\ddagger C D 3+$ denotes a composite population of cells comprising $(C D 3+/ C D 19+/ C D 14+)$ separated by immunodepletion. Poly, polyclonal; Mono, monoclonal; Poly(s), skewed X-inactivation in this patient. 


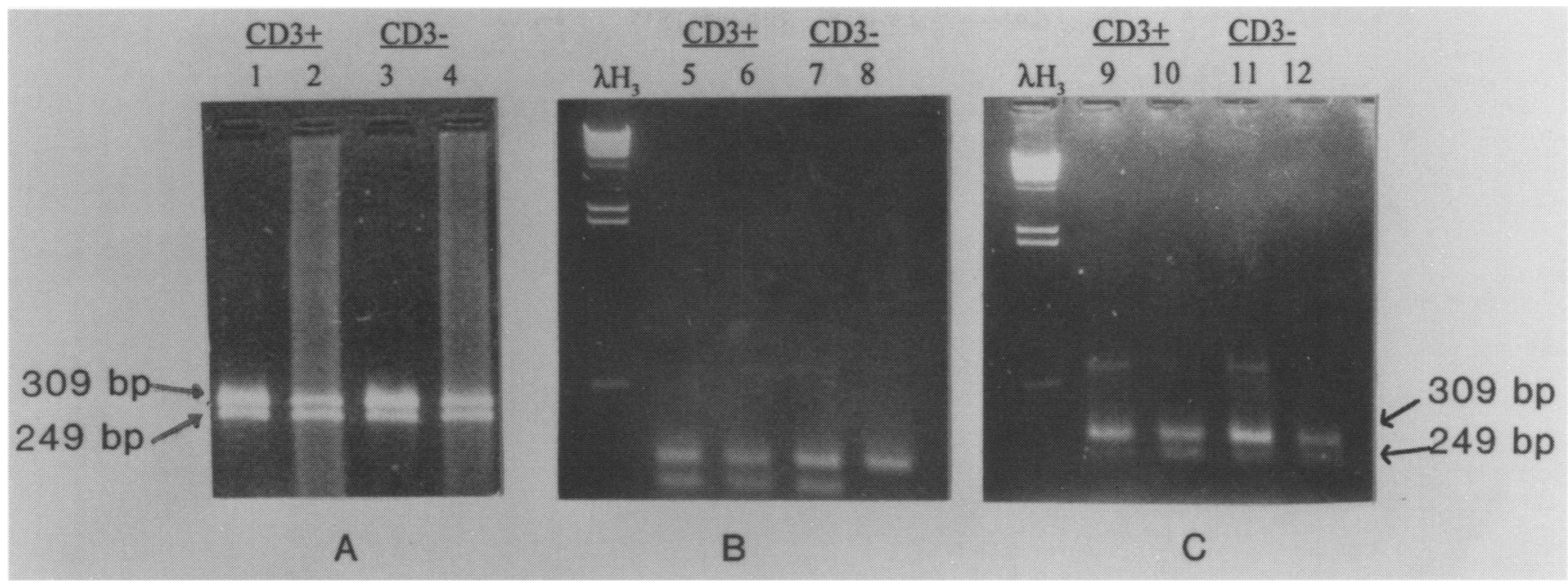

Figure $2 X$-inactivation analysis by the PCR method. Lanes $1,3,5,7,10$, and 12 show control products amplified without predigestion with HpaII. Lanes 2, 4, 6, 8, 9, and 11 show $X$-inactivation patterns when $P C R$ follows predigestion with HpaII. (A) Example of polyclonal band patterns in both $C D 3+$ and CD3 - cell fractions (case AB). (B) Example of monoclonal band pattern in CD3- cell fraction only (case WF). (C) Example of skewed $X$-inactivation in both $C D 3+$ and $C D 3-$ cell fractions (case WD).

was less than $2 \%$. In practice, this rarely required more than two depletion steps. The Dynabead bound fraction comprised CD14+ (monocyte), CD19+ (B lymphocyte), and $\mathrm{CD} 3+(\mathrm{T}$ lymphocyte) cells. For simplicity this fraction is referred to as CD3 + in fig 2.

\section{DNA EXTRACTION}

For TCR analysis extraction was performed by a standard phenol/chloroform method after $0.86 \mathrm{M}$ ammonium chloride lysis of red cells and overnight digestion with proteinase $\mathrm{K} .{ }^{14} \mathrm{~A}$ simplified protocol was used for $\mathrm{X}$-inactivation analysis following lymphocyte fractionation. Cells were resuspended in $1 \mathrm{ml}$ of sodium chloride/TRIS/EDTA (pH8) (STE) buffer, lysed with $20 \mu \mathrm{l}$ sodium dodecyl sulphate (SDS) $(20 \% \mathrm{w} / \mathrm{v})$ and treated with $100 \mu \mathrm{g}$ proteinase $\mathrm{K}$ for two hours, then extracted once with equal volumes of phenol and chloroform, ethanol precipitated, and pelleted. The dried pellet was resuspended in $100-200 \mu \mathrm{l}$ of TRIS/EDTA (pH7.5) (TE) buffer.

T CELL RECEPTOR AND IMMUNOGLOBULIN HEAVY CHAIN GENE REARRANGEMENTS

DNA $(10 \mu \mathrm{g})$ was digested overnight with restriction enzymes HindIII and BamHI (and $E c o$ RI when results were inconclusive). The DNA fragments were separated using $0.8 \%$ agarose gel and transferred to nylon membranes (Hybond N, Amersham International, UK) using vacublotting method (Pharmacia, UK). The membranes were fixed by ultraviolet light and prehybridised at $65^{\circ} \mathrm{C}$ in buffer solution containing $10 \%$ dextran sulphate, $3 \times$ sodium citrate and sodium chloride (SSC), $1 \%$ sodium dodecyl sulphate (SDS), and denatured salmon sperm DNA, $10 \mathrm{mg} / \mathrm{ml}$, for two hours. Denatured ${ }^{32} \mathrm{P}$ labelled cDNA probes were added to the mixture and hybridised overnight. The probes used in this study were: Jur- $\beta 2,{ }^{15} \quad \mathrm{~T}-\gamma \quad(\mathrm{pH} 60),{ }^{16} \mathrm{~T}-\delta$ $(\mathrm{R} 21 \mathrm{XH}),{ }^{17}$ and $\mathrm{J}_{\mathrm{H}}(\mathrm{pUC1}){ }^{18}$ The membranes were washed twice in $2 \times$ SSC solution for five minutes at room temperature and in $2 \times$ SSC and $1 \%$ SDS for 30 minutes at $65^{\circ} \mathrm{C}$. Further washes were given if the background radioactivity was still high. The membranes were autoradiographed (Hyperfilm, Amersham International, UK) for three to five days.

\section{X-INACTIVATION CLONAL ANALYSIS BY THE PCR METHOD}

Primers A1/B3 for the 619 base pair product from the PGK gene were made on Applied Biosystems oligonucleotide synthesiser according to the sequence published elsewhere. ${ }^{11}$ Primer INT3 was also synthesised which produces a fragment of 309 base pairs enabling greater separation of Bst XI digested fragments. The sequence of the 20 nucleotide oligomer INT3 is TTGGTGGTTTCTAGCCGCATT (fig 1).

The PCR was carried out in an LEP Scientific, model Prem, thermal cycler. Temperatures were $95^{\circ} \mathrm{C}$ for one minute, denaturation, $56^{\circ} \mathrm{C}$ for one minute, annealing and $72^{\circ} \mathrm{C}$ for one minute extension. Amplification with primers $\mathrm{A} 1$ and $\mathrm{B} 3$ was for 25 cycles using $1.5 \mathrm{U}$ Taq polymerase (Promega) per tube in a total volume of $50 \mu \mathrm{l}$. Primers INT3 and B3 were used by taking $1 \mu 1$ of the 619 base pair A1/B3 product and a further 10 cycles of amplification carried out under the same PCR conditions. Digests of $0.5 \mu \mathrm{g}$ DNA with $20 \mathrm{U}$ HpaII enzyme (Northumbria Biologicals) were carried out in $20 \mu \mathrm{l} \mathrm{Taq}$ buffer (Promega) before amplification. This digest $(10 \mu \mathrm{l})$ was used for PCR. Control DNA was not digested with HpaII before amplification. Following amplification $20 \mu \mathrm{l}$ of products from both control and HpaII digested samples were digested overnight with $12 \mathrm{U}$ BstXI enzyme (Northumbria Biologicals). Fragments were separated using $2 \%$ agarose gel and visualised with ethidium bromide (fig 2 ).

\section{Results}

IMMUNOPHENOTYPING

The immunological characteristics of the six patients who were informative for PGK are 


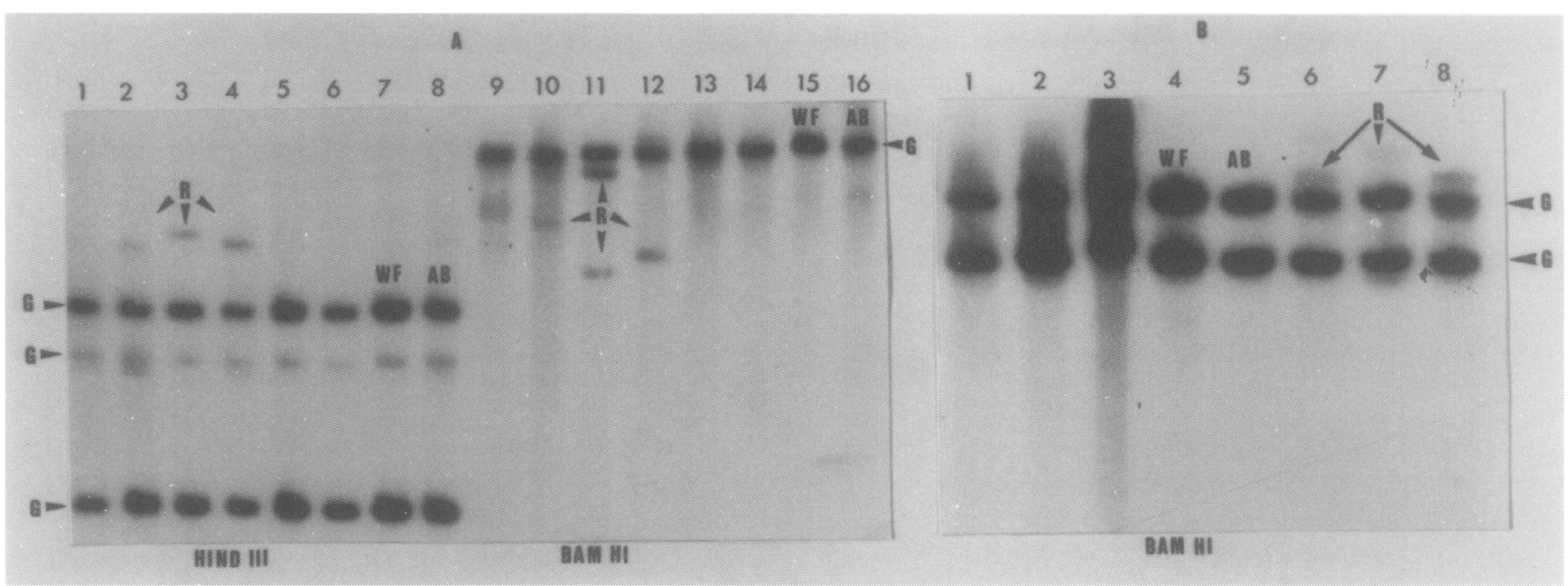

Figure 3 Southern blot analysis of $T$ cell receptor genes. (A) $\beta$ chain $A$ analysis. HindIII and BamHI digests of CD3- LGL cases WF and AB show germline $(G)$ configurations. For HindIII Lanes 1, 5, 6 negative controls; lanes 2-4 positive control samples showing rearranged $(R)$ clonal band patterns. For BamHI Lanes 13, 14 negative controls; lanes 9-12 positive control samples. (B) $\gamma$ chain B analysis. BamHI digests of CD3-LGL cases WF and $A B$ again show germline configuration. Lanes $1-3$ are negative controls, lanes $6-8$ are positive controls.

shown in table 1 . Absolute lymphocyte counts were only slightly increased (range 4.7-6.3 $\times$ $10^{9} / 1$ ) in four of these, the remaining two being within normal limits. Absolute increases in $\mathrm{CD} 2$ + CD3 - lymphocytes (normal range, $\left.0.15-0.49 \times 10^{9} / 1\right)$, which are primarily associated with natural killer associated cells, were found in all six cases, and multiple colour flow cytometry showed that the primary natural killer cell abnormality was associated with $\mathrm{CD} 2+\mathrm{CD} 3-\mathrm{CD} 4-\mathrm{CD} 8-(\mathrm{n}=4)$ or $\mathrm{CD} 2+\mathrm{CD} 3-\mathrm{CD} 4-\mathrm{CD} 8 \mathrm{dim}+(\mathrm{n}=2)$ fractions. Expression of natural killer cell associated determinants showed some individual variability but the abnormally increased $\mathrm{CD} 2+\mathrm{CD} 3-$ cell numbers in all cases expressed all four natural killer cell associated markers examined (CD11b, CD16, CD56, and CD57) on at least $30 \%$ of the cell fraction.

\section{T CELL RECEPTOR AND IMMUNOGLOBULIN HEAVY CHAIN GENE REARRANGEMENTS}

DNA from the mononuclear cell fractions of 17 patients with persistent expansions of CD3 - natural killer associated cells were investigated for the presence of monoclonal TCR and immunoglobulin gene rearrangements. Figure 3 illustrates germline and rearranged results obtained by this method. All of our 17 cases were found to have germline configuration with each probe used, which is illustrated by results from cases WF and $A B$ (fig 3). $T$ and $B$ cell gene rearrangement studies are carried out using a mononuclear cell fraction. Previous experience in the laboratory indicates that other cell types present in the mixture do not obscure the presence of a minor (as low as $1 \%$ ) population of cells containing a single clonal rearrangement. Germline bands represent unrearranged genes from most of the cells, whereas clonally rearranged cells appear as a distinct band of a different size (fig $3 \mathrm{~A}$; lanes 2-4).
$\mathrm{X}$-INACTIVATION ANALYSIS OF UNFRACTIONATED MONONUCLEAR CELLS Initially, DNA from the mononuclear cell fractions of 17 patients with persistent CD3 lymphocytosis were screened for the presence of a BstXI polymorphism at the PGK locus. Six heterozygotes were identified and $\mathrm{X}$-inactivation clonal analysis was carried out by the PCR method. None of these showed unequivocal evidence of monoclonality, although cases WF, LG, and WD (data not shown) produced highly "skewed" band patterns, with one product being significantly more intense than the other. These observations could either reflect an unusually high ratio of maternal:paternal $\mathrm{X}$-inactivated or suggest the existence of a mixture of clonal and nonclonal cells. Because $\mathrm{X}$-inactivation studies cannot distinguish cell type, cells not involved in the clone will interfere with the analysis. Therefore, the population of interest must be as pure as possible for meaningful analysis.

\section{X-INACTIVATION ANALYSIS OF}

IMMUNOLOGICALLY FRACTIONATED CELLS

To isolate the abnormally increased CD3cell numbers, fresh samples of peripheral blood mononuclear cells from each patient were separated into $\mathrm{CD} 3$ + and $\mathrm{CD} 3$ - fractions. Clonal analysis by the PCR method was then carried out on these subfractions. Results from case $\mathrm{AB}$ are shown in fig $2 \mathrm{~A}$, and show a polyclonal pattern in both $\mathrm{CD} 3+$ and $\mathrm{CD} 3-$ fractions, where both bands are retained after HpaII digestion. Similarly, cases ZB and AW gave polyclonal patterns (table 2 ). In contrast, results from case WF in fig 2B showed a polyclonal pattern of products in the CD3 + fraction and a monoclonal pattern in the CD3fraction (by the loss of one product from the CD3 - fraction after HpaII digestion). Likewise, patient LG showed a polyclonal pattern for the CD3 + fraction and a monoclonal pattern for the CD3- fraction (table 2). Results for case WD are shown in fig $2 \mathrm{C}$. This case 
shows evidence of uneven (skewed) $\mathrm{X}$-inactivation in both the $\mathrm{CD} 3+$ and $\mathrm{CD} 3-$ fractions, shown by a reduction of intensity of the smaller PCR product in the HpaII digested sample compared with the control. The observation was consistent over three experiments (data not shown) and as the pattern was the same for both the CD3 + and CD3 fractions we concluded that each comprised normal polyclonal subpopulations. The skew towards one $\mathrm{X}$-inactivation product is assumed to be consistent for constitutional DNA in this patient because of the comparison with $\mathrm{CD} 3$ + cells. In this case there was a slight difference in band intensity in control lanes (fig 2C; lanes 10, 12). This was seen occasionally and might have resulted from a PCR artefact due to template preference, or differences in ethidium bromide incorporation within the agarose gel. However, there was a clear difference between control lanes and HpaII digested samples (fig 2C; lanes 9, 11).

\section{Discussion}

Evidence for monoclonality in LGL disorders with CD3 + phenotype has been accumulating for several years by the extensive use of TCR gene rearrangement studies. ${ }^{8919}$ These studies, however, have served to confirm the consistent observation of germline TCR genes in LGL with CD3 - phenotype. This agrees with our own finding of germline TCR genes in the mononuclear cells of 17 CD3 - LGL cases, whereas in $\mathrm{CD} 3+$ cases rearrangements can be clearly seen (fig 3). Consequently, a $\mathrm{T}$ cell specific genetic marker seems to be inappropriate in the assessment of clonality in CD3 - LGL cases.

As there is no specific clonal marker available for cells of natural killer cell lineage we applied the lineage independent method of $\mathrm{X}$-inactivation analysis. A preliminary study of mononuclear DNA from CD3- LGL cases showed that polyclonal cells were present in the peripheral blood of these patients; but skewing of the bands suggested that in some cases there could be a subpopulation of clonal cells present within the mononuclear fraction. This was confirmed when fresh samples were divided into $\mathrm{CD} 3+$ and $\mathrm{CD} 3-$ subgroups and analysed separately. Of six informative cases examined, two patients clearly showed a monoclonal pattern in the CD3 - cell fraction. Polyclonal patterns were found for the $\mathrm{CD} 3+$ fraction of both of these patients, therefore effectively serving as tissue specific internal controls, showing that $\mathrm{X}$-inactivation is not extreme within the normal cells of these individuals. Extreme skew of $\mathrm{X}$-inactivation was, however, illustrated by another of our patients (WD) who showed evidence of a skewed $\mathrm{X}$-inactivation pattern within both cell fractions. This highlights the need for caution when interpreting reduced band intensity as a measure of clonality by the $\mathrm{X}$-inactivation method, particularly if constitutional DNA is not available. ${ }^{20}$ Fortunately, $\mathrm{CD} 3+$ cells provided suitable constitutional
DNA for this study.

The study of minor subpopulations of cells within the peripheral blood has become practicable by the development of a PCR based technique. This has the advantage of rapidity and has a reduced requirement for starting material compared with the standard Southern blotting method. ${ }^{1011}$ This limitation also applies to other Southern blotting based markers, such as HPRT and M27 $\beta$. M27 $\beta$ may not be ideal as an alternative because the test region suffers from hypermethylation in some leukaemic blast cells. ${ }^{20}$

Analysis of subpopulations makes it possible to isolate and identify the clonal origin of proliferating LGL cells and define the limits of lineage involvement. The abnormal monoclonal population in CD3 - LGL seems to be restricted to the natural killer cell subpopulation. Thus the target cell is shown to be committed to the natural killer cell lineage, the remaining peripheral blood cells having a polyclonal pattern of $\mathrm{X}$-inactivation. Other evidence for monoclonality in CD3- LGL has been found by Taniwaki et al, ${ }^{21}$ whose patients had chromosomal abnormalities, and by Kawa-Ha et $a l,^{22}$ who examined their cases for the presence of monoclonal Epstein-Barr virus termini and suggested the virus may have an aetiological role in some cases of LGL. In contrast, a recent report by Nash et $a l^{23}$ did not identify clonal CD3 - populations within the seven patients studied.

The clinical relevance of a clonal population of natural killer cells is uncertain. Neither of our two patients had any other evidence of an haematological malignancy. One patient (WF) had a strong history of autoimmune disease. The association of clonality with autoimmune disease is well recognised and is seen both in the manifestation of autoantibodies and clonal proliferation of large granular lymphocytes. ${ }^{24-26}$ The other patient (LG) had no clinical problems known to be associated with clonal proliferation. The increasing use of new molecular techniques is likely to permit identification of previously unidentified minor clonal populations. However, the clinical importance of this can only be ascertained by continued clinical observation.

We are grateful to the Yorkshire Leukaemia Group who participated in the survey of LGL proliferations. Thanks go to Dr T H Rabbitts for generously supplying $T-\gamma$, to Dr T Villiamy for $J_{H}$ and $T-\delta$, and to $D r J H$ Pringle for $J \beta 2$ probes. Thanks also go to Mr A Speight for technical assistance. AK was supported by the Yorkshire Cancer Research Campaign.

1 Newland AC, Catovsky D, Linch D, Cawley JC, Beverley $P$, San Miguel JF, et al. Chronic T-cell lymphocytosis: a review of 21 cases. Br $\mathcal{f}$ Haematol 1984;58:433-66.

2 Hamblin TJ. Interleukin-2 and lymphokine activated killer cells. Transfusion Sci 1991;12:35-42.

3 Ohno T, Kanoh T, Arita Y, Fujii H, Kuribayashi K, Masuda $\mathrm{T}$, et al. Fulminant clonal expansion of large granular lymphocytes: characterisation of their morphology, genotype and function. Cancer 1988;62:1918-2

4 Bennett JM, Juliusson G, Mecucci C. Morphologic, immunologic and cytogenetic classification of the chronic (mature) B and T lymphoid leukaemias: fourth meeting of the MIC Co-operative Study Group. Cancer Res 1990;50:2212.

5 Scott CS, Richards SJ, Sivakumaran M, Short M, Child JA, Hunt KM, et al. Transient and persistent expansions of large granular lymphocytes (LGL) and NK-associated cells: the Yorkshire Leukaemia Group Study. Br $\mathcal{f}$ Haematol 1993;83:504-15. 
6 Scott CS, Richards SJ. Classification of large granular lymphocyte (LGL) and NK-associated (NKa) disorders. Blood Rev 1992;6:220-33.

7 Rabbitts TH, Stinson A, Forster A, Foroni L, Luzzatto L, Catovsky $\mathrm{D}$, et al. Heterogeneity of $\mathrm{T}$-cell receptor beta chain gene rearrangements in human leukaemias and lymphomas. $E M B O$ ₹ $1985 ; 4: 2217-24$.

8 Sivakumaran M, Richards SJ, Hunt KM, Steed AJ, Bynoe AG, Morgan MM, et al. Patterns of CD16 and CD56 expression in persistent expansions of $\mathrm{CD} 3+\mathrm{NKa}+$ expression in persistent expansions of $\mathrm{CD} 3+\mathrm{NKa}+$ lymphocytes are predictive for clonal $T$ cell receptor

9 Loughran TP, Starkebaum G, Kidd P, Neiman P. Clonal proliferation of large granular lymphocytes in rheumatoid arthritis. Arthritis Rheum 1988;31:31-6.

10 Vogelstein B, Fearon ER, Hamilton SR, Freisinger AC, Willard HF, Michelson AM, et al. Clonal analysis using recombinant DNA probes from the X-chromosome. Cancer Res 1987;47:4806-13.

11 van Kamp $H$, Janssen $R$, Willemze $R$, Fibbe WE, Landegent JE. Studies on clonality by PCR analysis of the PGK-1 gene. Nucleic Acids Res 1991;19:2794.

12 Wagner L, Base W, Weisholzer M, Sexl V, Bognar H, Worman CP. Detection of BLT substrate-specific proteases in individual human peripheral blood leukocytes and bone marrow cells: applications to the classification of leukaemia. F Immunol Methods 1991;142:147-55.

13 MacKarill ID, Scott CS, Stark AN, Limbert HJ, Master PS, Jones RA, et al. A rapid method for the preparation of chromic chloride solutions for use in the direct rosetting technique. Med Lab Sci 1987;44:401-44.

14 Sambrook J, Fritsch EF, Maniatis T. Purification of nucleic acids. In: Molecular Methods: a laboratory manual-2nd edn. New York: Cold Spring Harbour Laboratory Press. 1989. Appendix (E) 3 .

15 Yoshikai Y, Anatoniou D, Clark SP, Yanagi Y, Sangster R, Van Den Elsen $P$, et al. Sequence and expression of transcripts of the human $T$-cell receptor $\beta$-chain genes. Nature 1984;312:521-4.

16 Lefranc M-P, Rabbitts TH. Two tandemly organised human genes encoding $\mathrm{T}$-cell $\gamma$ constant region miple rearrangements in different $\mathrm{T}$ cell types. Nature 1985;316:464-6.

17 Boehm T, Buluwela L, Williams D, White L, Rabbitts TH. A cluster of chromosome $11_{p} 13$ translocations found via distinct $D-D$ and $D-D-J$ rearrangements of the human $\mathrm{T}$ cell receptor delta chain gene. EMBO $f$ 1988;7:2011-17.

18 Early $P$, Huang $H$, Davis $M$, Calame $K$, Hood L. An immunoglobulin heavy chain gene is generated from 3 immunoglobulin heavy chain gene is generated from 3

19 Sansoni P, Girasole G, Manara GC, Snelli G, Passeri G, Allavena $P$, et al. Lymphocytes of a patient with lymphoproliferative disease of large granular lymphocytes express high natural killer, ADCC and LAK activity. Clin Immunol Immunopathol 1990;56:9-21.

20 Gale RE, Wheadon H, Goldstone AH, Burnett AK, Linch DC. Frequency of clonal remission in acute myeloid leukaemia. Lancet 1993;341:138-42.

21 Taniwaki $M$, Tagawa S, Nishigaki $H$, Horiike S, Misawa S, Shimazaki C, et al. Chromosomal abnormalities define clonal proliferation in CD3 - large granular lymdefine clonal proliferation in CD 3 - large granular

22 Kawa-Ha K, Ishihara S, Ninomiya T, Yumura-Yagi K, Hara J, Murayama F, et al. CD3-negative lymphoproliferative disease of granular lymphocytes containing Epstein-Barr viral DNA. $\mathcal{F}$ Clin Invest 1989;84:51-5.

23 Nash R, McSweeney P, Zambello R, Semenzato G, Loughran TP. Clonal studies of CD3 - lymphoproliferative disease of granular lymphocytes. Blood 1993;81: 2363-8.

24 Viard JP, Bach JF. Clonality in autoimmune diseases. Semin Haematol 1991;28:57-65.

25 Loughran TP, Starkebaum G, Aprile JA. Rearrangement and expression of $T$-cell receptor genes in large granular and expression of T-cell receptor genes in large

26 Stamenkovic I, Stegagno M, Wright KA, Krane SM, Amento EP, Colvin RB, et al. Clonal dominance among T-lymphocyte infiltrates in arthritis. Proc Natl Acad Sci, USA 1988;85:1179-83. 